\title{
Determination of characteristics of substructure and orientation inhomogeneity in polycrystalline specimens
}

\author{
E.E.Badiyan, A.G.Tonkopryad, O.V.Shekhovtsov, \\ R.V.Shurinov, T.R.Zetova, K.S.Kazachkova
}

\author{
V.Karazin Kharkiv National University, \\ 4 Svobody Sq., 61022 Kharkiv, Ukraine
}

\section{Received February 4, 2014}

The possibility of using color orientation maps obtained from the surface of polycrystalline specimens to determine the characteristics of the substructure and the orientation inhomogeneity has been studied experimentally. It is shown that a consistent and independent review of the color orientation maps in hues of red, green, blue and gray colors, and use of specially developed technique for the visualization of color hues which are not visually different on the color orientation maps allow not only to receive all the necessary characteristics of the substructure and the orientation inhomogeneity, but to study of their change in situ under plastic deformation of the samples.

\footnotetext{
Экспериментально исследована возможность использования цветовых ориентационных карт, полученных от поверхности поликристаллических образцов, для определения характеристик субструктурной и ориентационной неоднородности. Показано, что последовательное и независимое рассмотрение цветовых ориентационных карт в оттенках красного, зеленого, синего и серого цветов, а также использование специально разработанной методики визуализации визуально неразличимых на цветовой ориентационной карте оттенков цвета позволяют получать не только все необходимые характеристики субструктурной и ориентационной неоднородности, но и следить за их изменением in situ в процессе пластического деформирования образцов.
}

Визначення характеристик субструктурної $\mathbf{i}$ орієнтаційної неоднорідності в полікристалічних зразках. Є.Ю.Бадіян, А.Г.Тонкопряд, О.В.Шеховцов, Р.В.Шурінов, Т.Р.Зєтова, К.С.Казачкова.

Експериментально досліджено можливість використання колірних орієнтаційних карт, отриманих від поверхні полікристалічних зразків, для визначення характеристик субструктурної і орієнтаційної неоднорідності. Показано, що послідовний і незалежний розгляд колірних орієнтаційних карт у відтінках червоного, зеленого, синього та сірого кольорів, а також використання спеціально розробленої методики візуалізації візуально нерозпізнаних на колірній орієнтаційній карті відтінків кольору дозволяють отримувати не тільки всі необхідні характеристики субструктурної і орієнтаційної неоднорідності, але й стежити за їх зміною in situ в процесі пластичного деформування зразків.

\section{Introduction}

It is well known that the structure, substructure and orientation inhomogeneity affects the physical and more mechanical properties of crystalline materials. Therefore, the problem of determining the orientation and structure inhomogeneity of crystalline specimens seems quite important and actual. As a rule, the inhomogeneity is determined by diffraction methods [1] from a small area of 


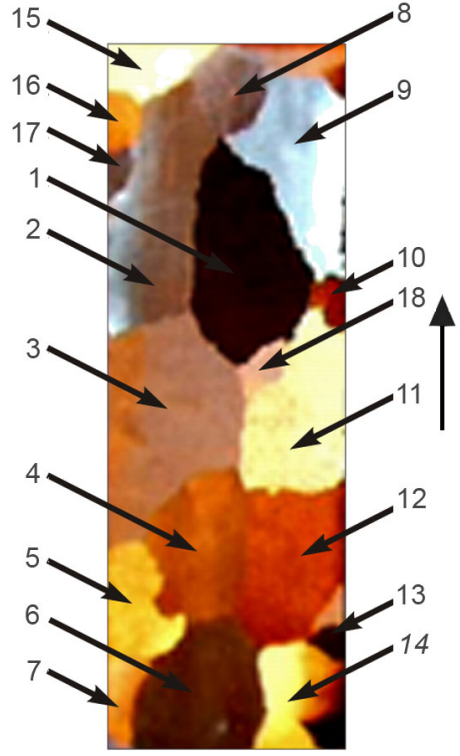

a)

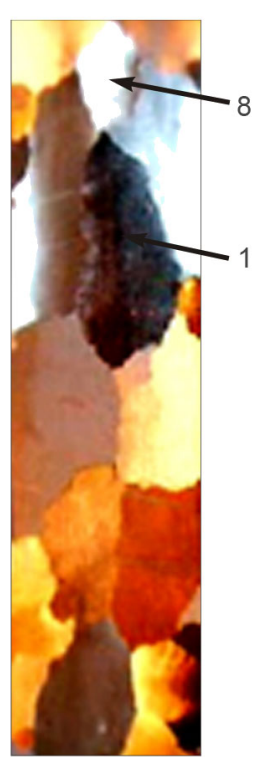

b)
Fig. 1. Color orientation maps of Al polycrystalline specimen surface before deformation (a) and after deformation by $26 \%$ (b)

the specimen as compared to its size. These methods do not allowed in situ to study of structural and orientational changes in specimens during external action. The developed opto-electronic technique [2-5] for the study of orientation and structure inhomogeneity of the surface of crystalline specimens allows to solve this problem.

\section{Experimental}

The technique is based on the observed effect of diffraction of white light by quasiperiodic etching relief of the surface of the crystalline materials [5]. The recording scheme includes a special lighting system and a digital photosensitive device connected to

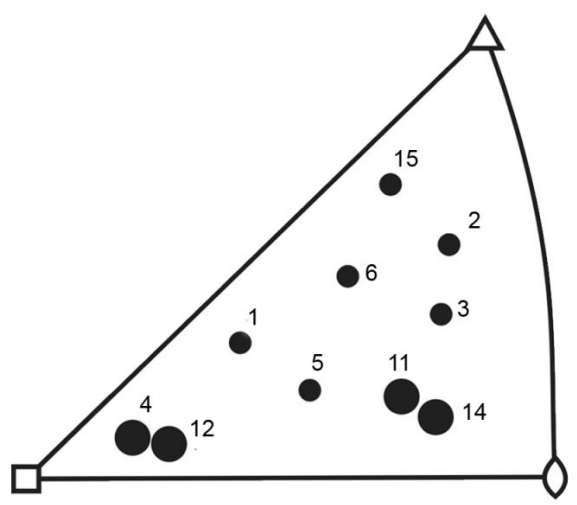

a) computer. It allows to obtain the color orientation maps [6-8] of the whole surface of a specimen in the RGB space, where the crystallographic orientation of individual segment of the specimen's surface and the color of it image is in one correspondence.

Large grained $(\bar{a} \approx 10 \mathrm{~mm})$ aluminum specimens have been used as objects of the study. The specimens of about $100 \times 20 \times 0.15 \mathrm{~mm}^{3}$ size were cut out from aluminum fine-grained foil (99.96\%). The polished specimens were strained in conditions of uniaxial tension by $\varepsilon=2.5 \%$ after annealing at $400^{\circ} \mathrm{C}$ during $3 \mathrm{~h}$. Necessary average grain size of about $10 \mathrm{~mm}$ was provided by subsequent recrystallization annealing at $620^{\circ} \mathrm{C}$ during $5 \mathrm{~h}$. The grain structure and the quasiperiodic relief of the specimen's surface [5] were determined by chemical etching during 20-40 $\mathrm{s}$ at the room temperature using Keller etchant: $\mathrm{HCl}$ $30 \mathrm{ml}, \mathrm{HNO}_{3} 20 \mathrm{ml}$, HF $5 \mathrm{ml}, \mathrm{H}_{2} \mathrm{O} 30 \mathrm{ml}$. The specimens were strained under active tension conditions at a constant straining rate $\dot{\varepsilon}=10^{-4} \mathrm{~s}^{-1}$ at the room temperature.

\section{Results and discussion}

Figure 1 shows the color orientation maps of Al polycrystalline specimen surface before deformation and after failure $(\varepsilon=$ $26 \%)$. The images of grains with different crystallographic orientation visibly differ in color hues. The crystallographic orientations of all grains (Fig. 2) relative to two directions, i.e., the normal to the grain surface and towards of the specimen axis direction, shown by the arrow in Fig. 1, were identified by X-ray diffraction. The crystallographic orientation of different parts of grain 1 was identified.

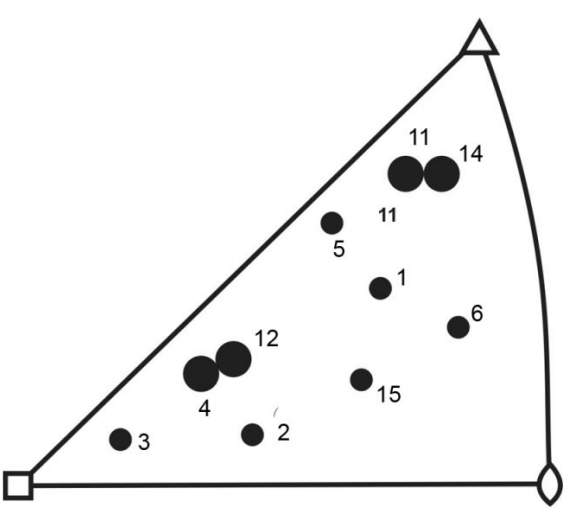

b)

Fig. 2. Crystallographic orientation of grains of Al polycrystalline specimen (Fig. 1a) relative to the normal to the grain surface (a) and direction shown by the arrow (b). 


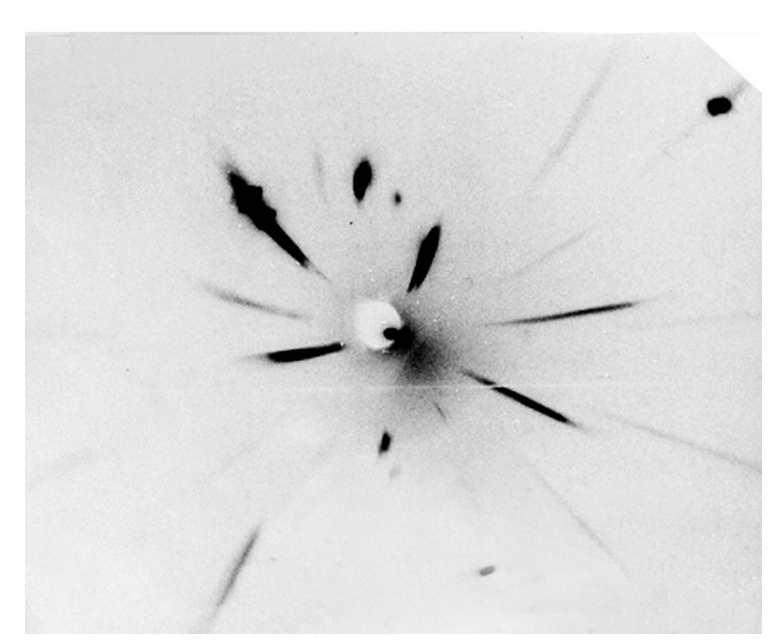

Fig. 3. Typical X-ray pattern of the grain after deformation of Al polycrystalline specimen by $26 \%$.

On the color orientation map grains 4 and 12,11 and 14 slightly differ visually (Fig. 1). Figure 2 shows that disorientation of the grains 4 and 12, 11 and 14 does not exceed five degrees.

It is shown experimentally that segments of the specimen's surface are isually different on the color orientation map, if their crystallographic disorientation does exceed several degrees. Identification of crystallographic orientation of the different segments of grain 1 shows that disorientation of these segments does not exceed the error of X-ray identification (Laue method). The asterism of the Laue spots is observed on $\mathrm{X}$-ray patterns of all the grains of the polycrystalline sample after its deformation by $26 \%$. This indicates that orientation inhomogeneity arise during deformation. Figure 3 shows the example of X-ray pattern of one of the grains after deformation of specimen by $26 \%$. Identification of crystallographic orientation of all the grains of $\mathrm{Al}$ polycrystalline specimen before deformation and after deformation by $26 \%$ show that orientation change during deformation in the most grains does not exceed several degrees. Such a change in the crystallographic orientation leads only to a slight change in hue of the color orientation maps of the specimen surface. The orientation changes during deformation of the sample do exceed 10 degrees for some grains (for example, grain 8). So there is a noticeable change in hue image of the surface of the grain on the color orientation maps.

It was ascertained experimentally that substructure and orientation inhomogeneity arise during plastic deformation in the grains of the polycrystalline specimen. Unfortunately, these results do not allow determining the characteristics of such inhomogeneity even for a small area of the specimen as compared to its size.

It should be noted that the RGB color space, where there is an ability to differentiate 16.7 million hues, was used for the color orientation mapping of the surface of Al polycrystal (Fig. 1). The number of hues of each of three primary colors is 256. Such a large number of color hues in the RGB color space does not allow to visualize area of the specimen's surface with a specific crystallographic orientation and clearly determine the correlation between the color hue of the specific area of the specimen's surface and its crystallographic orientation.

It was shown experimentally that for visualization of substructure and orientation inhomogeneity the color image of the specimen's surface can be considered consistently and independently in hues of red, green, blue or gray colors, which consists of the aforementioned color hues in identical proportions. It will be shown that such representation of the color orientation map allow, firstly, to reveal the correlation between the color hue of any area of the specimen's surface and its crystallographic orientation, secondly, to visualize the area of the specimen's surface with a different crystallographic orientation, thirdly, to determine quantitative characteristics of the substructure and orientation inhomogeneity and their changes in situ during external action. Parameter which characterizes the crystallographic orientation of the specimen's surface segment is the number $n$ of color image hue of this segment between the 256 possible hues of red, green, blue or gray colors.

Figure 4 shows an example of software processing of the digital image of the surface of grain 1 in hues of red before deformation and after deformation of the specimen by $26 \%$ in the form of graphs. The ordinate $N_{n}$ is area in pixels* of the segments of the grain with the same color hue, the abscissa $n$ is the number of this hue. Transition from pixels to $\mathrm{mm}^{2}$ can be made if you know the resolution of technique for color orientation mapping which depends on the resolution of digital camera and distance between the specimen surface and the camera. The PC-CAM 300 web camera allows color orientation mapping of the specimen surface at resolution of 100 pixels per $\mathrm{mm}^{2}$ when the distance between the 

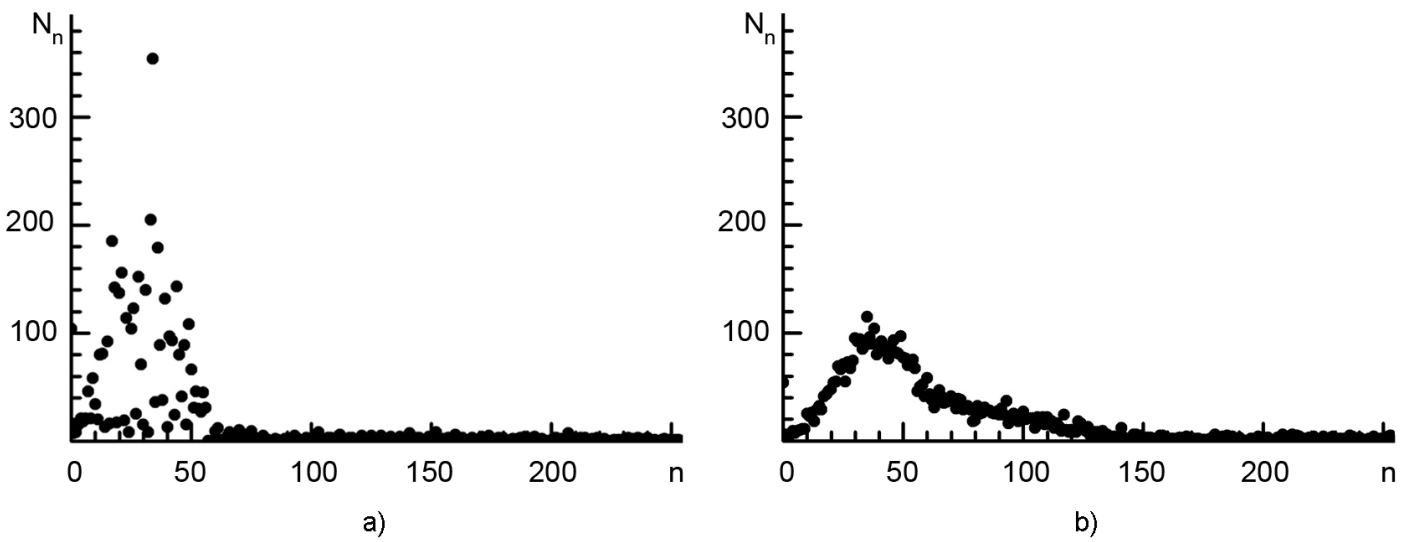

Fig. 4. Size distribution ( $N_{n}$ is area in pixels) and crystallographic orientation distribution ( $n$ is number of the color hue) of areas of the surface of grain 1 before deformation and after deformation of the specimen by $26 \%$.

specimen surface and the camera is $70 \mathrm{~mm}$. When using other (more sensitive to the color) camera a higher resolution can be achieved.

Experimental results (Fig. 4) allow qualitatively to study the substructure and orientation inhomogeneity of the specimen's surface and its change under plastic deformation. For example, we can show that the grain of the polycrystalline specimen has different substructure before deformation, and the plastic deformation, as a rule, leads to its crushing. Thus the spectrum of misorientation of the substructure elements $(\Delta n)$ is expanded. Values $N_{n}$, which characterize substructure, are the sum of all, including the visually indistinguishable on the color orientation map of grain, substructure elements scattered across its surface. Therefore it is impossible to determine the substructure characteristics and their changes under the plastic deformation.

Technique described below was proposed for visualization of the color hues, which are not visually different on the color image of the surface of the whole polycrystalline specimen or some of its grain, and determination of all the necessary characteristics of the substructure and orientation inhomogeneity, and also their changes in situ during external action.

The technique is based on replacing on the color orientation map the visually indistinguishable color hues to visually distinguishable color hues which are preselected from the RGB color space. The example of visualization of the orientation inhomogeneity of the surface of grain 1 is shown in Fig. 4 and Table 1 which contains the scheme of replacing the visually indistinguishable color hues to visually distinguishable ones.

Color distribution of image of the surface of grain 1 in hues of red color before deformation and after deformation of specimen by $26 \%$ is shown in Fig. 4. The ordinate $N_{n}$ is area in pixels of segment of the grain surface with the certain color hue $n$. The abscissa $n$ is number of the hue of red color, which varies from 0 to 255. From this figure, it is clear that the color image of the surface of grain 1 contains the red color hues in the range from 0 to 60 before deformation and in the range from 0 to 150 after deformation. Table 1 shows the sizes of areas of the color image of the grain's surface in pixels (first column, according to Fig. 4) with certain values of red color hues (second column). Thus, the area of the image of the grain's surface with hues of color in the range from 0 to 10 is 319 pixels, from 11 to 20 is 680 pixels, from 21 to 30 is 909 pixels, from 31 to 40 is 1196 pixels, from 41 to 50 is 703 pixels, from 51 to 60 is 276 pixels. The third column of Table 1 shows hues of red color of all the areas of the color image of the grain's surface which are presented in the first column. The results in this column show that the color image of all the considered areas is visually indistinguishable. The last two columns contain the visually distinguishable color hues, which are preselected from the RGB color space, and the corresponding values of $R, G$ and B. Figure 5 shows color orientation maps of the surface of grain 1 of specimen before deformation and after deformation by $26 \%$ after replacing the visually indis- 
Table 1. Scheme of replacing on the color orientation maps of the surface of grain 1 the visually indistinguishable color hues to visually distinguishable color hues which are preselected from the RGB color space

\begin{tabular}{|c|c|c|c|c|}
\hline$S$, pixel & $n$ & $\begin{array}{c}\text { Visually } \\
\text { indistinguishable } \\
\text { color hues }\end{array}$ & $\begin{array}{c}\text { Visually } \\
\text { distinguishable } \\
\text { color hues }\end{array}$ & $\mathrm{R}, \mathrm{G}, \mathrm{B}$ \\
\hline 319 & $0-10$ & & $\square$ & $255,0,0$ \\
\hline 680 & $11-20$ & & $\square$ & $0,255,0$ \\
\hline 909 & $21-30$ & & $\square$ & $0,0,255$ \\
\hline 1196 & $31-40$ & & $\square$ & $255,0,255$ \\
\hline 703 & $41-50$ & L & D & $255,255,0$ \\
\hline 276 & $51-60$ & & $\square$ & $0,255,255$ \\
\hline
\end{tabular}

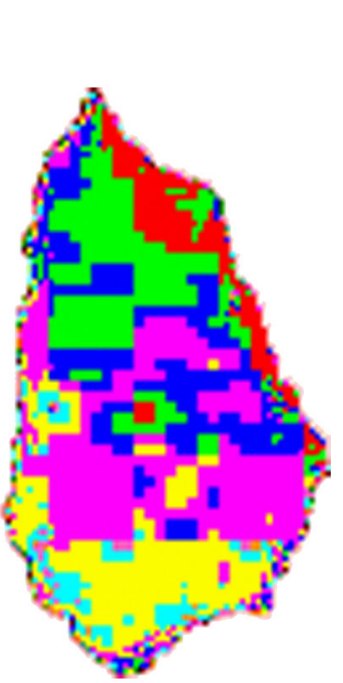

a)

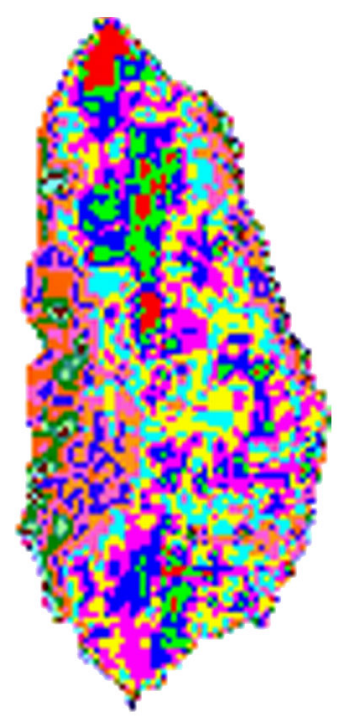

b)
Fig. 5. Color orientation maps of the surface of grain 1 after visualization of substructure and orientation inhomogeneity before deformation (a) and after deformation by $26 \%$ (b), $\times 5$.

tinguishable red color hues, which are presented in third column, to the visually distinguishable red color hues, which are presented in fourth column. Obtained color orientation maps illustrate the orientation and substructure inhomogeneity of the specimen's surface before deformation and after it.

It is easy to determine the sizes of areas of the color orientation maps of the specimen surface with certain hue of red, green, blue or gray colors which characterize substructure and orientation inhomogeneity. In this work, two-dimensional Al polycrystals which contain only through grain boundaries were used. In such specimens, substructure and orientation inhomogeneity of the surface indicates inhomogeneity of bulk.
Table 2. Average, minimum and maximum size of the subgrains before deformation and after deformation by $26 \%$

\begin{tabular}{|c|c|c|c||}
\hline$\varepsilon, \%$ & $L, \mathrm{~mm}$ & $L_{\min }, \mathrm{mm}$ & $L_{\max }, \mathrm{mm}$ \\
\hline 0 & $7(7)$ & $0.3(0.3)$ & $14(13)$ \\
\hline
\end{tabular}

Table 2 shows that the characteristics of substructure and orientation inhomogeneity on opposite surfaces of the specimen are almost identical.

\section{Conclusions}

Technique for study of orientation and substructure inhomogeneity of the surface of a polycrystalline specimen is experimentally justified. The suggested technique allows to determine all characteristics of such inhomogeneity which include the subgrain size distribution and crystallographic orientation distribution, average, maximum and minimum size of the subgrains.

Linear resolution of the technique is $0.5 \mu \mathrm{m}$ when using the PC-CAM 300 web camera.

The suggested technique allows in situ to study change of the substructural and orientational inhomogeneity in specimen under external action at a period of 0.02 second in all grains on the surface of a polycrystalline specimen simultaneously.

\section{References}

1. A.N.Ivanov, L.N.Rastorguev, Yu.A.Skakov, Ya.S.Umanskij, Kristallografiya, Rentgenografiya i Elektronnaya Mikroskopiya, ed. by Metallurgiya, Moskva (1982) [in Russian].

2. E.E.Badiyan, A.G.Tonkopryad, O.V.Shekhovtsov, R.V.Shurinov, Functional Materials, 13, 411 (2006). 
3. E.E.Badiyan, A.G.Tonkopryad, O.V.Shekhovtsov, R.V.Shurinov, Metallofizika i Noveishie Technologii, 30, 361 (2008).

4. E.E.Badiyan, A.G.Tonkopryad, O.V.Shekhovtsov, R.V.Shurinov, T.R.Zetova, Zavodskaya Laboratoriya. Diagnostika Materialov, 76, 34 (2010).

5. E.E.Badiyan, A.G.Tonkopryad, O.V.Shehovtsov, R.V.Shurinov, Inorganic Materials, 15, 1663 (2011).
6. J.J.Fundenbergera, A.Morawiecb, E.Bouzya, J.S.Lecomte, Ultramicroscopy, 96, 127 (2003).

7. D.P.Field, B.W.True, T.M.Lillo, J.E.Flinn, Mater. Sci. and Engin., A372, 173 (2004).

8. Masayuki Kamaya, A.J.Wilkinson, J.M.Titchmarsh, Nucl. Engin. and Design, 235, 713 (2005). 